\title{
Solubility and Availability of Heavy Metals in Soils as Affected by Compost Amendment
}

\author{
Mohamed L. Moharem
}

\begin{abstract}
The effect of agriculture solid waste compost on the availability of native and spiked $\mathrm{Cd}, \mathrm{Cu}, \mathrm{Ni}$, and $\mathrm{Zn}$ in three different soils was evaluated. The three soils were spiked separately with the metals at concentration of 800 mg kg soil ${ }^{-1}$ and amended with three rates of the compost $(0,3$, and $6 \%-w / w)$. The mixtures of soil-compost were allowed to age at room temperature for 30 and 90 days. After each period, they were extracted for readily soluble and exchangeable (2.5\% acetic acid), available (DTPA), and bound to organic matter (sodium pyrophosphate) metal species. Addition of compost generally reduced the extractability of the soluble and exchangeable forms of all native and spiked metals. This effect was directly related to the amount of added compost and increased with ageing time. The potentially plant-available $\mathrm{Cd}$ and $\mathrm{Cu}$ extracted with DTPA were generally reduced with increasing additions of compost and incubation time. There was increase of sodium pyrophosphate extractable $\mathrm{Cd}$ and $\mathrm{Cu}$ as a result of compost amendment and incubation time increase. Conversely, recovery of $\mathrm{Zn}$ in DTPA-extract was larger with increasing both compost and incubation period whereas $\mathrm{Ni}$ remained invariant with compost additions with slightly decrease in metal solubility during aging. The obtained results suggest that soil amendment with compost-organic matter may accelerate the immobilization of native and spiked heavy metals in soils due to reducing readily soluble and exchangeable all metals in addition to reducing possible plant uptake of- at least- $\mathrm{Cd}$ and $\mathrm{Cu}$.
\end{abstract}

Keywords: Solubility, Heavy metals, Compost, Incubation time.

\section{INTRODUCTION}

Soil contamination with heavy metals is a worldwide problem. Accumulation of heavy metals in soils can adversely affect soil ecology, agricultural productivity, quality of agricultural products and water resources, human and animal health problem (Raicevic et al., 2005). Among available remediation technologies, in situ immobilization of heavy metals using a chemical amendment can be a cost-effective and environmentally sustainable remediation approach for the immobilization of heavy metals by reducing the mobility and availability. This immobilization technique may provide a long-term remediation solution if low solubility minerals and/or stable precipitates are produced in situ (Vangronsveld and Cunningham, 1998). Therefore, the choice of the soil amendments need that the amendments must reduce heavy metals transfers from contaminated soils to the surface water or groundwater and uptake by plants and organisms.

Several authors have suggested the use of residual materials such as compost for in situ remediation of heavy metal contaminated soils, as the least ecologically damaging and least expensive remediation technique (Geebelen et al., 2002 and Nwachukwu and Pulford, 2008). Compost has been reported as having a great potential for retaining trace elements in non-available forms (Smith, 2009), potentially reducing their overall bioavailability due to several processes, including raising soil $\mathrm{pH}$, complexation, sorption, precipitation, or a combination of them, thus providing an effective soil remediation technique (Brown et al., 2003). However, some drawbacks may happen with this technique, namely the potential mobilization of some elements (in particular $\mathrm{Cu}$ ) associated to dissolved organic matter (Zhou and Wong, 2001), and the re-release of the immobilized elements after organic matter mineralization in the long term. These drawbacks can in fact be avoided, first, because high loads of dissolved organic matter are expected only when low-stabilized organic materials are employed, as their concentrations decrease with compost maturity. There is no evidence that trace element availability increases with time in compost-amended soil as a result of organic matter mineralization (Smith, 2009). Therefore, employing non-stabilized organic materials for this purpose should be avoided in order to keep the potential drawbacks at a minimum. Furthermore, compost materials may contain high levels of heavy metals depending on their source and may increase their contents in amended soil depending on the ability of compost components to bind metal in addition to various soil conditions. Therefore, this study was designed (1) to assess the effect of potentially metals originating from compost on metals forms in incubated soils and (2) to study the effect of compost amendment on native metals form and (3) to evaluate the behavior of heavy metals freshly added to soils during the incubation periods and (4) to examine the effect of compost amendment on freshly added metals form.

Regional center for Food and Feed, Agricultural Research center, 


\section{MATERIALS AND METHODS}

Soils:

Three soil samples, varying in organic matter and calcium carbonate contents, were used in this study. Sandy soil was collected from Elbostan, $80 \mathrm{Km}$ south west Alexandria city and calcareous soil from ElNahda, $40 \mathrm{Km}$ south west Alexandria city. Abu-Rawash soil was collected from Abu-Rawash area of Great Cairo city with historically irrigation with primary treated wastewater from Abu-Rwash wastewater treatment plant. The soil samples were air-dried, ground, passed through a 2-mm sieve and stored in plastic bags for use. Selected chemical and physical properties of the three soils are shown in Table 1. Soil $\mathrm{pH}$ was measured in 1:2 soil: water suspension and electric conductivity (EC) was measured in soil paste extract (Richards, 1954). The bioavailable $\mathrm{Cd}, \mathrm{Cu}, \mathrm{Zn}$ and Ni were extracted by DTPA (Lindsay and Norvell, 1978) and measured by atomic absorption spectroscopy (contrAA 300). Organic matter content was determined by the method of Walkley and Black (Nelson and Sommers, 1982), total carbonate equivalent was determined by calcimiter method (Nelson, 1982), and cation exchange capacity was measured by the method of Rhoades (1982). Metal concentrations were determined according to the method described by Ure (1995). Particle size analysis was determined by the hydrometer method (Hillel et al., 1972).

\section{Compost:}

Compost less than $5 \mathrm{~mm}$ derived from organic waste material mainly agriculture solid waste (ASW) were obtained from Nahdat Misr Company for Environmental services (formally was named Veolia) in Alexandria city. The analysis of the main properties of the compost was conducted as follows: $\mathrm{pH}$ was determined in aqueous extracts (substrate/extractant ratio: $1 / 5, \mathrm{v} / \mathrm{v})$. Total organic matter (OM) was determined by Walkley and Black (Nelson and Sommers, 1982). Total N was measured by Kjeldahl digestion of samples and steam distillation (Keeney and Nelson, 1982). Total concentrations of heavy metals in aqua regia digested extract (Esakku et al. 2005) were analyzed using flame atomic absorption spectrometry (contrAA 300). The main chemical properties of the compost are shown in Table 1.

\section{Incubation experiment:}

The soils were mixed by hand with the compost at two rates: $3 \%$ and $6 \%$ (dry weight), roughly equivalent to 60 and $120 \mathrm{t} \mathrm{ha}^{-1}$. The soils alone and the mixtures with compost were contaminated separately with a solution containing $\mathrm{Cu}\left(\mathrm{NO}_{3}\right), \mathrm{Cd}\left(\mathrm{NO}_{3}\right)_{2}, \mathrm{Zn}\left(\mathrm{NO}_{3}\right)_{2}$ or $\mathrm{Ni}\left(\mathrm{NO}_{3}\right)_{2}$ in order to obtain a final concentration of 800 $\mathrm{mg} \mathrm{kg}^{-1}$ (dry weight) for each element in soil. The soils were incubated for 30 or 90 days by the following treatments:

- Non-spiked soil and amended with each compost rate, to study the effect of potentially metals originating from compost on metals forms in incubated soils, and also to study the effect of compost amendment on native metals form.

- Spiked soil, to study the behavior of heavy metals freshly added to soils during the incubation periods.

- Spiked soil and amended with each compost rate, to study the effect of compost amendment on freshly metals form.

The moisture content was maintained throughout the experiment around $80 \%$ of their field capacity, replacing weight losses with distilled water. Composite samples were taken after each period and air-dried for analysis.

\section{Soil extractants:}

At the end of each incubation period, the incubated soils were extracted with the following solutions: (1) $2.5 \%$ glacial acetic acid $(\mathrm{v} / \mathrm{v})$, for readily soluble and easily exchangeable forms of metals (Alloway and Davis, 1971); (2) $0.005 \mathrm{M}$ DTPA in $0.01 \mathrm{~N} \mathrm{CaCl}_{2}$ and $0.1 \mathrm{M}$ triethanolamine at $\mathrm{pH}=7.3$, for plant-available metals (Lindsay and Norvell, 1978); (3) sodium pyrophosphate, for metals bound to organic matter. For first and second extractants, $10 \mathrm{ml}$ of solution were added to $5 \mathrm{~g}$ of soil sample placed in polypropylene bottles and shaken on a rotating shaker for $2 \mathrm{~h}$. The suspension was then filtered and the filtrate brought to $50 \mathrm{ml}$. For Pyrophosphate-extracted elements, one hundred milliliters of $0.1 \mathrm{M}$ Na-pyrophosphate were added to $1 \mathrm{~g}$ of soil and the resulting suspension was shaken for $16 \mathrm{~h}$ (McKeague, 1967). Five drops of $0.04 \%$ Superfloc were added to the extract before centrifugation in order to produce the flocculation of clay. The concentration of metals in the supernatant of the three extractants was measured with a flame Atomic Absorption Spectrometry (contrAA 300).

\section{RESULTS AND DISCUSSIONS}

The three soils chosen for this study differ substantially in their native $\mathrm{OM}$ and calcium carbonate content. The calcareous soil is characterized by high calcium carbonate content. In comparison with calcareous and sandy soils, Abu-Rawash soil showed more organic matter, higher CEC value and total content of $\mathrm{Cu}, \mathrm{Ni}$, and $\mathrm{Zn}$ (Table 1); considering the past irrigation with primary treated wastewater from Abu-Rwash wastewater treatment plant in the periodically area from which the Abu-Rawash soil was collected. 
Table 1. The main chemical and physical properties of the studied soils and compost

\begin{tabular}{|c|c|c|c|c|c|}
\hline Characteristics & Units & Calcareous & Sandy & Abu-Rawash & Compost \\
\hline $\mathrm{pH}$ & & 7.9 & 8.0 & 6.87 & 7.9 \\
\hline $\mathrm{EC}$ & $\mathrm{dS} \mathrm{m}^{-1}$ & 4.54 & 1.12 & 2.99 & 4.7 \\
\hline Clay & $\%$ & 26.8 & 19.4 & 1.3 & - \\
\hline Silt & $\%$ & 6.4 & 13 & 3.9 & - \\
\hline Sand & $\%$ & 66.8 & 67.6 & 94.8 & - \\
\hline Texture & & sandy clay loam & sandy & sandy & - \\
\hline $\mathrm{OM}$ & $\%$ & 1.5 & 0.4 & 3.21 & 75.16 \\
\hline $\mathrm{CaCO}_{3}$ & $\%$ & 26 & 19 & & - \\
\hline CEC & $\mathrm{cmol}_{\mathrm{c}} \mathrm{kg}^{-1}$ & 18 & 5 & 33 & 52 \\
\hline TOC & $\%$ & 0.87 & 0.23 & 1.86 & 43.70 \\
\hline $\mathrm{N}$ & $\%$ & - & - & - & 3.13 \\
\hline $\mathrm{C} / \mathrm{N}$ & & - & - & - & 14 \\
\hline Total metal & $\mathrm{mg} \mathrm{kg}^{-1}$ & & & & \\
\hline $\mathrm{Cu}$ & & 33.48 & 20.58 & 51.34 & 210.25 \\
\hline $\mathrm{Cd}$ & & 0.01 & 0.05 & - & - \\
\hline $\mathrm{Zn}$ & & 25.66 & 21.22 & 132 & 844.88 \\
\hline $\mathrm{Ni}$ & & 2.1 & 2.5 & 14.79 & 4.32 \\
\hline DTPA-extractable metal & $\mathrm{mg} \mathrm{kg}^{-1}$ & & & & \\
\hline $\mathrm{Cu}$ & & 5.21 & 3.56 & 5.23 & - \\
\hline $\mathrm{Cd}$ & & - & - & - & - \\
\hline $\mathrm{Zn}$ & & 1.33 & 0.63 & 12.34 & - \\
\hline $\mathrm{Ni}$ & & - & - & 2.12 & \\
\hline
\end{tabular}

EC: Electrical conductivity; OM: Organic matter; CEC: Cation exchange capacity; TOC: Total organic carbon; C/N: carbon : nitrogen ratio

The amount of soluble and exchangeable heavy metals recovered by extraction with $2.5 \%$ acetic acid in the three soils after two incubation periods are reported in Tables 2 and 3. The compost additions to soils which were not spiked with heavy metals were studied only for Abu-Rawash soil due to high content of native heavy metals comparing with the other two soils. However, native $\mathrm{Cd}$ of Abu-Rawash soil was not studied due to the non detected measurement of this metal in both soil and compost. As shown in Table 2, the solubility in acetic acid of the original heavy metals for the un-spiked Abu-Rawash soil produced a general decrease of the concentrasion of the acetic acidextractable metals as a result of compost addition to soil with more pronounced at high addition level. This effect was noticeable for the original content of all metals after both 30 and 90 days of incubation.

Following three soils individually enrichment with heavy metals, the quantity of metals recovered in $2.5 \%$ acetic acid for control samples (no compost addition) was significantly lower than the amount added to three soils (Table 3), thereby indicating that ageing processes control the extractability of heavy metals in soils. However, control soils showed a different ageing effect with diverse metals. While the solubility in acetic acid significantly decreased with incubation for all metals in the OM-rich Abu-Rawash soil or calcium carbonaterich calcareous soil, that of $\mathrm{Cd}$ and $\mathrm{Zn}$ did not significantly change in the period between 30 and 90 days for the $\mathrm{OM}$ and calcium carbonate-poor sandy soil. This suggests a role of the native OM or calcium carbonate of both soils in progressively increasing the retention of soluble and exchangeable heavy metals. The larger amount of native OM in the Abu-Rawash soil is capable to strongly complex all added metals which become less soluble in acetic acid, whereas the lower OM content in the sandy soil may have not been reactive enough to stabilize the weaker complexes with Cd and Zn (Stevenson and Ardakani, 1972; Stevenson, 1977). Furthermore, the high contents of $\mathrm{CaCO}_{3}$ in calcareous soil could be responsible for the high metals retention through incubation period of this soil (Ponizovsky et al., 2007; Basta et al., 2001; Mcbride, 1994).

The soils treated with increasing amounts of compost had the general effect of gradually reducing the solubility of heavy metals in acetic acid in respect to control(Table 3). Furthermore, incubation time generally reduced further the metals extractability, though differences between the three soils were noticed. For instance, $\mathrm{Cu}$ availability in sandy soil was decreased from 71 to $42 \mathrm{mg} \mathrm{kg}^{-1}$ after 30 day incubation time as a result of adding high compost level. 
Table 2. The amount of $2.5 \%$ acetic acid, DTPA, sodium pyrophosphate extractable native metals $\left(\mathrm{mg} \mathrm{kg}^{-1}\right)$ of compost amended Abu-Rawash soil after the 30 and 90 days of incubation

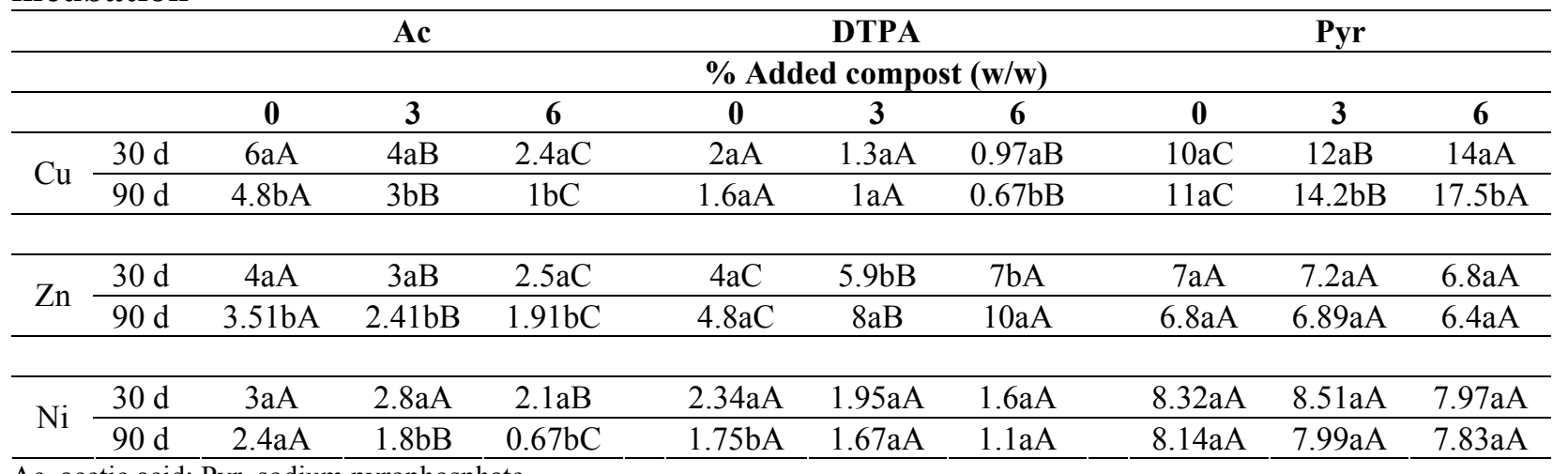

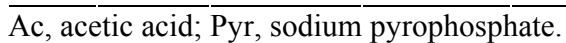

All values are average of three replications. Means within a (vertical) column for both incubation time followed by the same lower case letter do not differ significantly by the Duncan's multiple range test $(\mathrm{p}<0.05)$. Means within a (horizontal) row for a given level of \% compost addition followed by same capital case letter do not differ significantly by Duncan's multiple range test ( $\mathrm{p}<$ $0.05)$

Table 3. The amount of $2.5 \%$ acetic acid extractable spiked metals $\left(\mathrm{mg} \mathrm{kg}^{-1}\right)$ of the compost amended three soils after the 30 and 90 days of incubation

\begin{tabular}{|c|c|c|c|c|c|c|c|c|c|c|}
\hline & \multicolumn{3}{|c|}{ Calcareous } & \multicolumn{3}{|c|}{ Sandy } & \multicolumn{3}{|c|}{ Abu-Rawash } \\
\hline & & \multicolumn{9}{|c|}{ \% Added compost (w/w) } \\
\hline & & $\mathbf{0}$ & 3 & 6 & $\mathbf{0}$ & 3 & 6 & $\mathbf{0}$ & 3 & 6 \\
\hline \multirow{2}{*}{$\mathrm{Cd}$} & $30 \mathrm{~d}$ & $46 \mathrm{aA}$ & $40 \mathrm{aB}$ & $32 \mathrm{aC}$ & $198 \mathrm{aA}$ & $172 \mathrm{aB}$ & $108 \mathrm{aC}$ & $292 \mathrm{aA}$ & $242 \mathrm{aB}$ & $186 \mathrm{aC}$ \\
\hline & $90 \mathrm{~d}$ & $42.5 \mathrm{bA}$ & $33.5 \mathrm{bB}$ & $26 \mathrm{bC}$ & $196 \mathrm{aA}$ & $150 \mathrm{bB}$ & $80 \mathrm{bC}$ & $196 \mathrm{bA}$ & $140.5 \mathrm{bB}$ & $96.43 \mathrm{bC}$ \\
\hline \multirow{2}{*}{$\mathrm{Cu}$} & $30 \mathrm{~d}$ & $14 \mathrm{aA}$ & $13 \mathrm{aB}$ & $11 \mathrm{aC}$ & $71 \mathrm{aA}$ & $50 \mathrm{aB}$ & $42 \mathrm{aC}$ & $198 \mathrm{aA}$ & $166 \mathrm{aB}$ & $116 \mathrm{aC}$ \\
\hline & $90 \mathrm{~d}$ & $13 \mathrm{bA}$ & $11.1 \mathrm{bB}$ & $8 \mathrm{bC}$ & $60.34 \mathrm{bA}$ & $40.43 \mathrm{bB}$ & $29.5 \mathrm{bC}$ & $178.5 \mathrm{bA}$ & $144.5 \mathrm{bB}$ & $96 \mathrm{bC}$ \\
\hline \multirow{2}{*}{$\mathrm{Zn}$} & $30 \mathrm{~d}$ & $250 \mathrm{aA}$ & $238 \mathrm{aB}$ & $220 \mathrm{aC}$ & $363 \mathrm{aA}$ & $359 \mathrm{aB}$ & $309 \mathrm{aC}$ & $433 \mathrm{aA}$ & $420 \mathrm{aB}$ & $411.76 \mathrm{aC}$ \\
\hline & $90 \mathrm{~d}$ & $237 \mathrm{~b}$ & $234.5 \mathrm{~b}$ & $200 \mathrm{~b}$ & $360.5 \mathrm{bA}$ & $351 \mathrm{bB}$ & $242.5 \mathrm{bC}$ & $397 \mathrm{bA}$ & $340 \mathrm{bB}$ & $328.5 \mathrm{bC}$ \\
\hline \multirow{2}{*}{$\mathrm{Ni}$} & $30 \mathrm{~d}$ & $36 \mathrm{aA}$ & $20 \mathrm{aB}$ & $14 \mathrm{aC}$ & $73 \mathrm{aA}$ & $58 \mathrm{aB}$ & $46 \mathrm{aC}$ & $161 \mathrm{aA}$ & $154 \mathrm{aB}$ & $142 \mathrm{aC}$ \\
\hline & $90 \mathrm{~d}$ & $25.5 \mathrm{bA}$ & $17 \mathrm{bB}$ & $9 \mathrm{bC}$ & $52.5 \mathrm{bA}$ & $44 \mathrm{bB}$ & $30 \mathrm{bC}$ & $120 \mathrm{bA}$ & $119 \mathrm{bA}$ & $104 \mathrm{bB}$ \\
\hline
\end{tabular}

$\overline{\text { All values are average of three replications. Means within a (vertical) column for both incubation time followed by the same lower }}$ case letter do not differ significantly by the Duncan's multiple range test $(\mathrm{p}<0.05)$. Means within a (horizontal) row for a given level of \% compost addition followed by same capital case letter do not differ significantly by Duncan's multiple range test ( $\mathrm{p}<$ $0.05)$.

Moreover, after the second incubation period of this soil, additional reduction of $\mathrm{Cu}$ concentration was obtained reaching $29.5 \mathrm{mg} \mathrm{kg}^{-1}$. These findings suggest that compost amendments contribute strongly to reduce the solubility of heavy metals and presumably also their mobility in the soil solution.

DTPA solution is commonly used to estimate plantavailable metals (Lindsay and Norvell, 1978). This extractant can also evaluate the fraction of metals complexed by OM (Piccolo and Celano, 1992). The additions of compost to Abu-Rawash soil which were not spiked with heavy metals showed a decrease in
DTPA-extractable native $\mathrm{Cu}$, and this effect was increasing during metals aging by the compost amendment. In contrast, incubation time and compost amendment showed an increase of $\mathrm{Zn}$ solubility in DTPA extract whereas $\mathrm{Ni}$ recovery was not significantly affected by both incubation time and compost amendments (Table 2). The effect of compost on the availability of native metals in this soil can be referred to metal content/form in both soil and compost. High content of $\mathrm{Cu}$ and $\mathrm{Zn}$ is seen in both compost and Abu-Rawash soil (Table 1). Thus, the increase of $\mathrm{Zn}$ recovery due to compost amendment in contrast to what 
was noticed for $\mathrm{Cu}$ may be attributed to the difference in the chemical form of both metals in soil and compost.

Copper and zinc showed a different ability towards compost components. For example, He et al. (1995) showed that $>50-80 \%$ of $\mathrm{Zn}$ was extracted in a relatively labile organic fraction from municipal solid waste-composts. Copper, on the other hand, was bound to more humified organic matter (approximately 50\%) and was therefore considered to be relatively immobile. Thus, in the current study, the increase of DTPA extractable $\mathrm{Zn}$ as an increase of compost rate could be related to low ability of compost constituents for $\mathrm{Zn}$ retention leading to easily release of compost native $\mathrm{Zn}$ once increase of amendment rate. On the other hand, the high stability of $\mathrm{Cu}$ hold in compost matrix as discussed could be responsible for the low extractability of $\mathrm{Cu}$ in DTPA extract.

Values of metals in DTPA extraction from the three spiked soils are shown in Table 4. The DTPA solution was capable to extract significantly larger amount of metals than that of the acetic acid. The progressive increase of the compost additions decreased $\mathrm{Cd}$ and $\mathrm{Cu}$ solubility in DTPA. Further decrease in DTPA extractable $\mathrm{Cd}$ and $\mathrm{Cu}$ was obtained when incubation time passed from 30 to 90 day for the three soils. The highest stability constants for $\mathrm{Cu}$ in humic complexes (Schnitzer and Skinner, 1967; Stevenson, 1977) and the tendency of $\mathrm{Cd}$ to preferably associate with larger, humified, and less soluble organic materials (Kaschl et al., 2002) may account for the reduced availability of $\mathrm{Cu}$ and $\mathrm{Cd}$ with incubation time due to OM-rich compost amendment. These results indicate the role of organic matter originated from compost amended soils on reducing metals availability. This is in line with the findings of other researchers in the direction that compost inputs to contaminated soils containing large fractions of labile elements reduce their overall bioavailability (Smith, 2009 and Brown et al., 2003).

In contrast to what was generally observed for $\mathrm{Cd}$ and $\mathrm{Cu} ; \mathrm{Zn}$ and $\mathrm{Ni}$ behaved a contrast trend. The mean values of Ni recovered in DTPA were the lowest for all added metals and remained invariant with compost additions in the soils after each incubation period with slightly decrease in metal solubility during aging. Conversely, in the three soils the mean values of $\mathrm{Zn}$ were enhanced with the increase of both compost amendments and incubation time with respect to control. The low solubility of Ni in DTPA extract comparing with the other metals in addition to its independent behavior toward compost addition indicated the low ability of $\mathrm{Ni}$ toward organic matter since DTPA extractant can also solubilize metals chelated with organics (Piccolo and Celano, 1992). This result is in line with Schnitzer and Skinner (1967) who observed the low value of stability constant of this metal in complexes with humic matter. However, the slight decrease of DTPA-Ni with incubation time by the compost amendment may be due to the predominance of mineral species for $\mathrm{Ni}$ (Halim et al., 2003). It was reported that $\mathrm{Ni}$ can be strongly retained in soils as precipitates which may be considered an irreversible form on soils and minerals (Voegelin and Kretzschmar, 2005).

Table 4. DTPA extractable spiked metals $\left(\mathrm{mg} \mathrm{kg}^{-1}\right)$ of the compost amended three soils after the 30 and 90 days of incubation

\begin{tabular}{|c|c|c|c|c|c|c|c|c|c|c|}
\hline & & \multicolumn{3}{|c|}{ Calcareous } & \multicolumn{3}{|c|}{ Sandy } & \multicolumn{3}{|c|}{ Abu-Rawash } \\
\hline & & \multicolumn{9}{|c|}{ \% Added compost (w/w) } \\
\hline & & $\mathbf{0}$ & 3 & 6 & $\mathbf{0}$ & 3 & 6 & $\mathbf{0}$ & 3 & 6 \\
\hline \multirow{2}{*}{$\mathrm{Cd}$} & $30 \mathrm{~d}$ & $430 \mathrm{aA}$ & $412 \mathrm{aB}$ & $392 \mathrm{aC}$ & $614 \mathrm{aA}$ & $528 \mathrm{aB}$ & $464 \mathrm{aC}$ & $606 \mathrm{aA}$ & $574 \mathrm{aB}$ & $504 \mathrm{aC}$ \\
\hline & $90 \mathrm{~d}$ & $375.5 \mathrm{bA}$ & $347.5 \mathrm{bB}$ & $315 \mathrm{bC}$ & $598 \mathrm{bA}$ & $498 \mathrm{bB}$ & $405.5 \mathrm{bC}$ & $487.5 \mathrm{bA}$ & $429.5 \mathrm{bB}$ & $363 \mathrm{bC}$ \\
\hline \multirow{2}{*}{$\mathrm{Cu}$} & $30 \mathrm{~d}$ & $295 \mathrm{aA}$ & $284 \mathrm{aB}$ & $200 \mathrm{aC}$ & $427 \mathrm{aA}$ & $391 \mathrm{aB}$ & $390 \mathrm{aB}$ & $406 \mathrm{aA}$ & $391 \mathrm{aB}$ & $340 \mathrm{aC}$ \\
\hline & $90 \mathrm{~d}$ & $271.5 \mathrm{bA}$ & $239 \mathrm{bB}$ & $176 \mathrm{bC}$ & $415.5 \mathrm{bA}$ & $354 \mathrm{bB}$ & $339.5 \mathrm{bC}$ & $290.5 \mathrm{bA}$ & $253.5 \mathrm{bB}$ & $220 \mathrm{bC}$ \\
\hline \multirow{2}{*}{$\mathrm{Zn}$} & $30 \mathrm{~d}$ & $342 \mathrm{aC}$ & $345 \mathrm{bB}$ & $360 \mathrm{bA}$ & $395 \mathrm{aC}$ & $436 \mathrm{bB}$ & $473 \mathrm{bA}$ & $379 \mathrm{aC}$ & $387.3 \mathrm{bB}$ & $402 \mathrm{bA}$ \\
\hline & $90 \mathrm{~d}$ & $329 \mathrm{bC}$ & $350 \mathrm{aB}$ & $374 \mathrm{aA}$ & $378 \mathrm{bC}$ & $443 \mathrm{aB}$ & $490 \mathrm{aA}$ & $358.5 \mathrm{bC}$ & $398 \mathrm{aB}$ & $443.5 \mathrm{aA}$ \\
\hline \multirow{2}{*}{$\mathrm{Ni}$} & $30 \mathrm{~d}$ & $99 \mathrm{aA}$ & $98 \mathrm{aA}$ & $98.6 \mathrm{aA}$ & $76 \mathrm{aB}$ & $77 \mathrm{aA}$ & $78 \mathrm{aA}$ & $88 \mathrm{aA}$ & $87.2 \mathrm{aA}$ & $87.1 \mathrm{aA}$ \\
\hline & $90 \mathrm{~d}$ & $94.5 \mathrm{bA}$ & $95 \mathrm{bA}$ & $94.1 \mathrm{bA}$ & $70.5 \mathrm{bA}$ & $71.3 \mathrm{bA}$ & $69.2 \mathrm{bA}$ & $86 \mathrm{bA}$ & $85 \mathrm{bA}$ & $84.8 \mathrm{bB}$ \\
\hline
\end{tabular}

$\overline{\text { All values are average of three replications. Means within a (vertical) column for both incubation time followed by the same lower }}$ case letter do not differ significantly by the Duncan's multiple range test $(\mathrm{p}<0.05)$. Means within a (horizontal) row for a given level of \% compost addition followed by same capital case letter do not differ significantly by Duncan's multiple range test $(\mathrm{p}<$ 0.05). 
Table 5. Sodium pyrophosphate extractable spiked metals $\left(\mathrm{mg} \mathrm{kg}{ }^{-1}\right)$ of the compost amended three soils after the 30 and 90 days of incubation

\begin{tabular}{|c|c|c|c|c|c|c|c|c|c|c|}
\hline & & \multicolumn{3}{|c|}{ Calcareous } & \multicolumn{3}{|c|}{ Sandy } & \multicolumn{3}{|c|}{ Abu-Rawash } \\
\hline & & \multicolumn{9}{|c|}{ \% Added compost (w/w) } \\
\hline & & $\mathbf{0}$ & $\mathbf{3}$ & 6 & $\mathbf{0}$ & 3 & 6 & $\mathbf{0}$ & $\mathbf{3}$ & 6 \\
\hline \multirow{2}{*}{$\mathrm{Cd}$} & $30 \mathrm{~d}$ & $208 \mathrm{bC}$ & $221 \mathrm{bB}$ & $247 \mathrm{bA}$ & $60.32 \mathrm{aC}$ & $77.32 \mathrm{bB}$ & $85.12 \mathrm{bA}$ & $330.5 b C$ & $369.3 \mathrm{bB}$ & $403.5 \mathrm{bA}$ \\
\hline & $90 \mathrm{~d}$ & $213 \mathrm{aC}$ & $231 \mathrm{aB}$ & $275 \mathrm{aA}$ & $61.32 \mathrm{aC}$ & $85.43 \mathrm{aB}$ & $96.5 \mathrm{aA}$ & $336.32 \mathrm{aC}$ & $379 \mathrm{aB}$ & $430 \mathrm{aA}$ \\
\hline \multirow{2}{*}{$\mathrm{Cu}$} & $30 \mathrm{~d}$ & $220 \mathrm{bC}$ & $263 \mathrm{bB}$ & $277 \mathrm{bA}$ & $66.1 \mathrm{aC}$ & $78 \mathrm{bB}$ & $90 \mathrm{bA}$ & $390 \mathrm{bC}$ & $432 \mathrm{bB}$ & $442 \mathrm{bA}$ \\
\hline & $90 \mathrm{~d}$ & $228 \mathrm{aC}$ & $286 \mathrm{aB}$ & $320 \mathrm{aA}$ & $67.5 \mathrm{aC}$ & $89 \mathrm{aB}$ & $121 \mathrm{aA}$ & $392 \mathrm{aC}$ & $461 \mathrm{aB}$ & $565 \mathrm{aA}$ \\
\hline \multirow[b]{2}{*}{$\mathrm{Zn}$} & $30 \mathrm{~d}$ & $11 \mathrm{aA}$ & $12 \mathrm{aA}$ & $10 \mathrm{aA}$ & 7.32aA & $7.9 \mathrm{aA}$ & $7.8 \mathrm{aA}$ & $12.32 \mathrm{aA}$ & $11.9 \mathrm{aA}$ & $11.3 \mathrm{aA}$ \\
\hline & $90 \mathrm{~d}$ & $\begin{array}{c}11.2 b \\
\mathrm{~A}\end{array}$ & $10 \mathrm{bA}$ & $8 \mathrm{bB}$ & $7.3 \mathrm{aA}$ & $7.1 \mathrm{bA}$ & $7 \mathrm{bA}$ & $11.8 \mathrm{aA}$ & $10.5 \mathrm{bA}$ & $9.45 \mathrm{bB}$ \\
\hline \multirow{2}{*}{$\mathrm{Ni}$} & $30 \mathrm{~d}$ & $\begin{array}{c}13.2 \mathrm{a} \\
\mathrm{A} \\
\end{array}$ & $12.8 \mathrm{aA}$ & $12.5 \mathrm{aA}$ & $8.32 \mathrm{aA}$ & $8.11 \mathrm{aA}$ & 7.9aA & $13.2 \mathrm{aA}$ & $13.9 \mathrm{aA}$ & $12.9 \mathrm{aA}$ \\
\hline & $90 \mathrm{~d}$ & $\begin{array}{c}12.5 \mathrm{a} \\
\mathrm{A}\end{array}$ & $11.7 \mathrm{bA}$ & $11.4 \mathrm{bA}$ & $8.1 \mathrm{aA}$ & $7.9 \mathrm{aA}$ & $7 \mathrm{bB}$ & $12.8 \mathrm{bA}$ & $12.7 \mathrm{bA}$ & $11.9 \mathrm{bB}$ \\
\hline
\end{tabular}

All values are average of three replications. Means within a (vertical) column for both incubation time followed by the same lower case letter do not differ significantly by the Duncan's multiple range test $(\mathrm{p}<0.05)$. Means within a (horizontal) row for a given level of \% compost addition followed by same capital case letter do not differ significantly by Duncan's multiple range test ( $\mathrm{p}<$ $0.05)$.

The contrast response between $\mathrm{Cd}, \mathrm{Cu}$ and $\mathrm{Zn}$ toward compost may be referred to the different affinity of these metals to complex with organic matter. Several researchers showed the potential of compost as sorbent for $\mathrm{Cu}$ and $\mathrm{Cd}$ rather than $\mathrm{Zn}$ (Grimes et al., 1999; Song and Greenway, 2004), suggesting that humic substances were likely to be the main sites of metal sorption. Additionally, McBride (1994) reported that $\mathrm{Zn}$ is less strongly sorbed to organic matter than $\mathrm{Cu}$; and this is due to the stronger binding sites for $\mathrm{Cu}$ by virtue of its lower electronegativity and higher charge to radius ratio, and also to the higher affinity of $\mathrm{Zn}$ for iron oxides.

Values for metals recovered by sodium pyrophosphate extraction after 30 and $90 \mathrm{~d}$ of incubation for native and freshly added metals are shown in Tables 2 and 5. This extractant is commonly used to estimate the pool of elements associated to organic matter (Paradelo et al., 2011). For $\mathrm{Cd}$ and $\mathrm{Cu}$, in general, both native and spiked metals were increased in the organic fraction as a result of compost amendments. The increase of incubation time of the three soils from 30 to 90 days in the presence of compost caused additional increase of both metals in sodium pyrophosphate extract with more intense at the highest rate of compost. For instance, at high compost amendment rate in sandy soil, $\mathrm{Cu}$ produced increasing in that fraction linked to organic matter, comparing with control, reaching almost a 36 and $79 \%$ at the end of the first and second incubation period, respectively. This result validates the hypotheses that metals sorption process onto organic matter may be responsible for increasing metal retention in compost amended soils. In contrary, $\mathrm{Zn}$ and Ni illustrated an independent behavior toward organic matter since in most cases both metals were not significantly changed with compost additions in the soils after each incubation period. Moreover, Ageing of $\mathrm{Zn}$ and $\mathrm{Ni}$ in soils reduces even its solubility in sodium pyrophosphate, reflecting a poor incorporation of both metals into organic matter.

\section{CONCLUSIONS}

The present study indicates that the potential environmental availability of native and freshly added metals to soils may be controlled by soil amendment with compost substance. The availability of metals, for both native and freshly added, in the $2.5 \%$ acetic acid extraction was generally reduced with compost amendment. This suggests that the "passive" physical mobility of metal species in soils (diffusion, mass transport) and the consequent risk of lateral and vertical contamination of water bodies may be effectively reduced with addition of reactive compost amendment. The potential availability of native and spiked $\mathrm{Cd}$ and $\mathrm{Cu}$ to plant uptake, an "active" process carried-out by root-exuded organic acids, that is mimicked by the wellestablished soil extraction with DTPA, generally diminished in soil amended with compost addition. 
Also, ageing of metals in samples magnifies the effect of compost amendment in the three soils. In contrary, the predominance of $\mathrm{Ni}$ and $\mathrm{Zn}$ to mineral species rather than organic matter may be responsible for the independent response of Ni to DTPA extraction and the increase of DTPA extractable $\mathrm{Zn}$ due to compost amendment. The fraction associated with organic matter (pyrophosphate-extractable) confirms that the mechanism of availability reduction by compost amendment was probably the association of $\mathrm{Cu}$ and $\mathrm{Cd}$ with organic matter.

These results showed that - at least for $\mathrm{Cd}$ and $\mathrm{Cu}-$ the amendment of metal-contaminated soils with compost could be an effective method for soil remediation due to the reduction of the mobility and availability of potentially toxic elements. Another advantage of using compost is suggesting that, at least at the rates employed here, the compost will not act as a source of contaminants even in case of $\mathrm{Zn}$ that while compost amendment is potentially useful to increase plant-availability of $\mathrm{Zn}$ in soil suffering from precipitation problem, they concomitantly reduce the environmental mobility and migration of this metal far from rhizosphere. The current results appear encouraging for an experimental upscale that verifies the role of compost in reducing plant uptake of heavy metals in soils contaminated with toxic metals.

\section{REFERENCES}

Alloway, B.S. and B.E. Davis. 1971. Trace element content of soils affected by base mining in Wales. Geoderma 5: 197207.

Basta, N.T., R. Gradwohl, K.L. Snethen, and J.L. Schorden. 2001. Chemical immobilization of lead, zinc and cadmium in smelter contaminated soils using biosolids and rock phosphate. J. Environ. Qual. 30: 1222-1230.

Brown, S.L., C.L. Henry, R. Chaney, H. Compton, and P.S. DeVolder. 2003. Using municipal biosolids in combination with other residuals to restore metalcontaminated mining areas. Plant Soil 249: 203-215.

Esakku, S., A. Selvam, J. Kurian, K. Palanivelu .2005. Assessment of heavy metal species in decomposed municipal solid waste. Chem. Spec. Bioavailab. 17:95102.

Geebelen, W., J. Vangronsveld, D.C. Adriano, R. Carleer, and H. Clijsters. 2002. Amendment induced immobilization of lead in a lead-spiked soil: Evidence from phytotoxicity studies. Water Air Soil Pollut. 140: 261-277.

Grimes, S.M., G.H. Taylor, and J. Cooper. 1999. The availability and binding of heavy metals in compost derived from household waste. J. Chem. Technol. And Biotechnol. 74:1125-130.

Halim, M., P. Conte, and A. Piccolo. 2003. Potential availability of heavy metals to phytoextraction from contaminated soils induced by exogenous humic substances. Chemosphere 52: 265-275.
He, X.T., T.J. Logan, and S.J. Traina. 1995. Physical and chemical characteristics of selected U.S. municipal solid waste composts. J. Environ. Qual. 24:543-52.

Hillel, D., V.D. Krentos, and Y. Stylianov. 1972. Procedure and test of an internal drainage method for measuring soil hydraulic characteristic in situ. Soil Sci. 114:395-400.

Kaschl, A., V. Romheld, and Y. Chen. 2002. Cadmium Binding by Fractions of Dissolved Organic Matter and Humic Substances. J. Environ. Qual. 31:1885-1892.

Keeney, D.R. and D.W. Nelson. 1982. Nitrogen-inorganic forms, in: A.L. Page (Ed.), Methods of Soil Analysis. Part 2. Chemical and microbiological properties, Am. Soc. Agron., Madison, pp. 643-698.

Lindsay, W.L. and W.A Norvell,. 1978. Development of a DTPA soil test for zinc, iron, manganese, and copper. Soil Sci. Soc. Amer. J. 42:421-428.

McBride, M. B. 1994. Environmental Chemistry of Soils. Oxford University Press, New York.

McKeague, J.A. 1967. An evaluation of 0.1M pyrophosphatedithionite in comparison with oxalate as extractants of the accumulation products in podzols and some other soils. Can. J. Soil Sci. 46: 13-22.

Nelson, D.W. and L.E. Sommers. 1982. Total carbon, organic carbon and organic matter. In: Page AL, Miller RH, Keeney DR (eds) Methods of Soil Analysis. Am. Soc. Of Agron., Madison,Wisconsin, USA, pp 539-549.

Nelson, R.E. 1982. Carbonate and gypsum. In: Page AL, Miller RH, Keeney DR (eds) Methods of Soil Analysis. Amer. Soc. Agron., Madison, pp 181-197.

Nwachukwu, O.I. and I.D. Pulford. 2008. Comparative effectiveness of selected adsorbant materials as potential amendments for the remediation of lead, copper and zinccontaminated soil. Soil Use Manage. 24: 199-207.

Paradelo, R., A. Villada, A.R. Devesa-Rey, A.B. Moldes, M. Domínguez, J. Patĩno, and M.T. Barral. 2011. Distribution and bioavailability of trace elements in municipal solid waste composts. J. Environ. Monitor. 13: 201-211.

Piccolo, A. and G. Celano. 1992. Distribution of heavy metals in profiles of a hydromorphic soil system. Fres. Environ. Bull. 1: 16-21.

Ponizovsky, A., H.E. Allen, and A.J. Ackerman. 2007. Copper activity in soil solutions of calcareous soils. Environ. Pollut. 145: 1-6.

Raicevic, S., T. Kaludjerovic-Radoicic, and A.I. Zouboulis. 2005. In situ stabilization of toxic metals in polluted soils using phosphates: Theoretical prediction and experiment verification. J. Hazard. Mater. 117: 41-53.

Rhoades, J. D. 1982. Cation exchange capacity. In: A.L. Page (ed.) Methods of Soil Analysis. Part 2: Chemical and microbiological properties ( $2^{\text {nd }}$ ed.) Agronomy 9:149-157.

Richards, L.A. 1954. Dignosis and improvement of alkaline soils. USDA Handbook 60. US Government Printing Office, Washington, DC, USA, p 152. 
Scheidegger, A.M., D.G. Strawn, G.M. Lamble, and D.L. Sparks. 1998. The kinetics of mixed Ni-Al hydroxide formation on clay and aluminum oxide minerals: A timeresolved XAFS study. Geochim. Cosmochim. Ac. 62:2233-2245.

Schnitzer, M. and S.I.M. Skinner. 1967. Organo-metallic interactions in soils: Stability constants of $\mathrm{Pb}, \mathrm{Ni}, \mathrm{Co}, \mathrm{Ca}$ and $\mathrm{Mg}$-fulvic acid complexes. Soil Sci. 103: 247- 252.

Smith, S.R. 2009. A critical review of the bioavailability and impacts of heavy metals in municipal solid waste composts compared to sewage sludge. Environ. Int. 35: 142-156.

Song, Q.J. and G.M. Greenway. 2004. A study of the elemental leachability of and retention capability of composts. J. Environ. Monitoring 6:31-37.

Stevenson, F.J. 1977. Nature of divalent transition metal complexes of humic acids revealed by modified potentiometric titration method. Soil Sci. 103: 10-17.
Stevenson, F.J. and M.S. Ardakani. 1972. Organic matter reactions involving micronutrients in soils. In: Mortvedt, J.J. (Ed.), Micronutrients in Agriculture. American Society of Agronomy, Madison.

Ure, A.M. 1995. Methods of soil analysis for heavy metals in soils. In: Alloway BJ (ed) Heavy metals in soils, $2^{\text {nd }}$ edn. Blackie Academic and Professional, London, pp 58-95.

Vangronsveld, J. and S.D. Cunningham. 1998. Introduction to the Concepts. Metal-Contaminated Soils: In-Situ Inactivation and Phytorestoration. Pp: 1-15.

Voegelin, A. and R. Kretzschmar. 2005. Formation and dissolution of single and mixed $\mathrm{Zn}$ and $\mathrm{Ni}$ precipitates in soil: Evidence from column experiments and extended Xray absorption fine structure spectroscopy. Environ. Sci. Technol. 39:5311-5318.

Zhou, L.X. and J.W.C. Wong. 2001. Effect of dissolved organic matter from sludge and sludge compost on soil copper sorption. J. Environ. Qual. 30: 878-883. 


\section{الملذص العري \\ تالثيرالفة الكمبوست علي ذائبية وصلاحية الهناصر القيلة في الأراضي \\ محمد لطفي محرم}

الكومبوست تؤوي إلي القليل من خطورة ذائبية وحركة

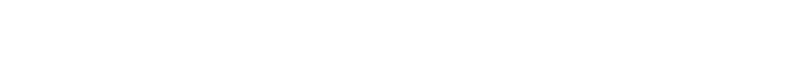
الأراضي بالكمبوست يلعب دورا هلما في القليل من لأخطار تلوث الماء الأرضي بالعناصر القيلة.

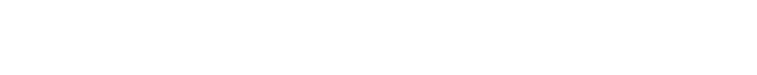
عنصري الكاميوم والنطس المستخلص بل المبال

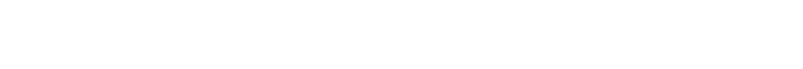

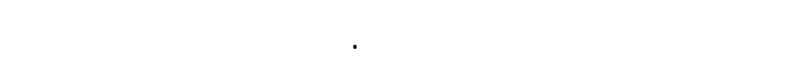
تكوين معقدات غير ذائبة بين العنصر والمادة العضوية فئنية

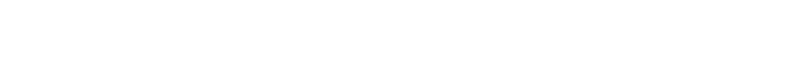

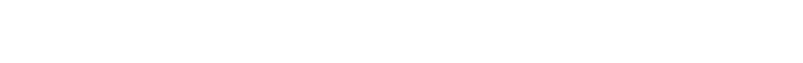

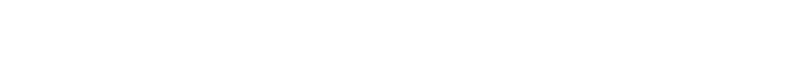
التحضين. وعلي القيض، زاد تركيز الزيك المستخلص بل فيل

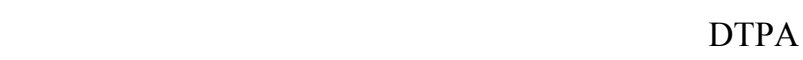
مدة التحضين والذي يمكن أن يعتبر ميزة في الأراضي في مئي

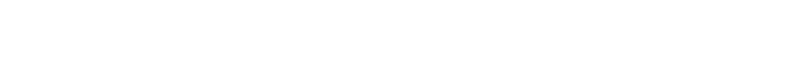
للنيكل فقد لظهربسلوكا غير متأثرا بإضافة الكمبوست. النتائج النهائية نشير إلي إمكانية لإستخدلم الكمبوست

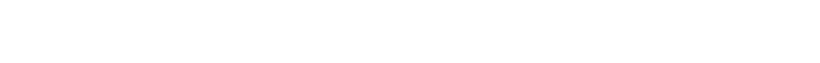

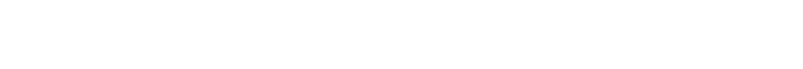

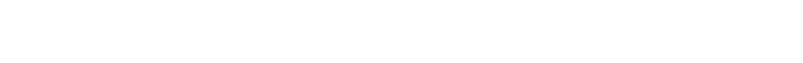

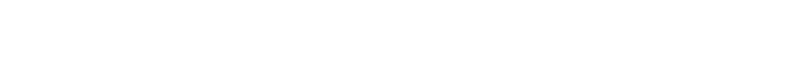

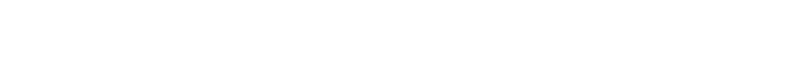
وصول هذه العناصر اللسلمة إلي سلسلة غذاء الإنسلن والحيوان.
لجريت هذه الدرلسة لقييم إِيتخدلم الكمبوست، المتحصل عليه من المخلفت الزراعية، علي الإتلحة

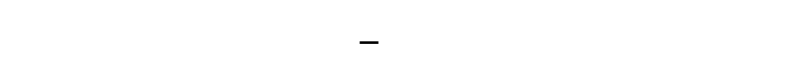

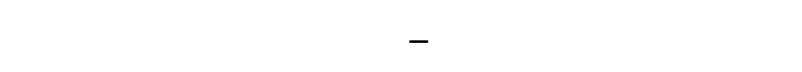
المختلفة في الخواص الكيميائية ومحتوي العناصر القيلة.

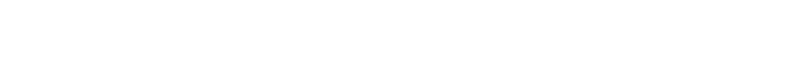

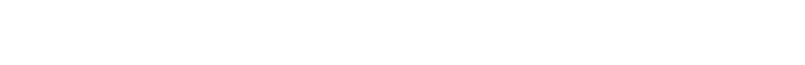

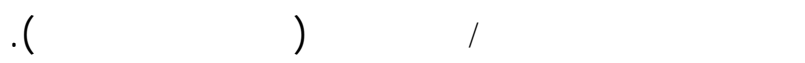

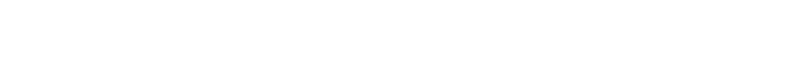

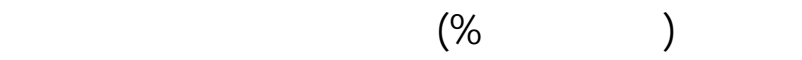

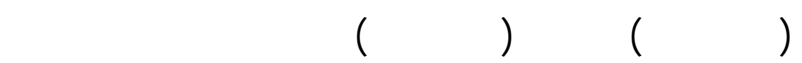
لبيلن تأثير زمن التحضين علي ذائبية العناصر.

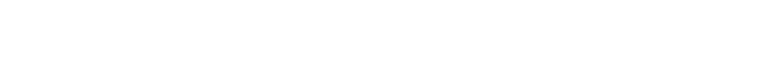

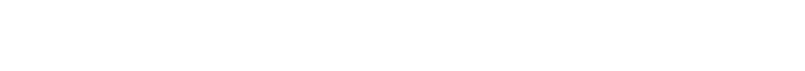
مختلفة من المستخلصت وهي مستخلص حلمض الخليك لبيان الصورة الذائبة والمتبادلة للعنصر والقابلة للحركة خلا قاع التربة، مستخلص DTPA لبيان صورة العنصر

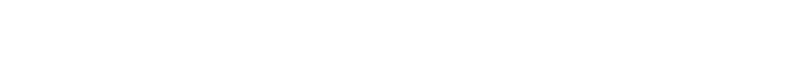
بيرفوسفات الصويوم لبيان صورة العنصر المرتبط بالماة العضوية.

أوضحت نتائج الدرلسة أن إضلفة الكمبوست أيي إلي

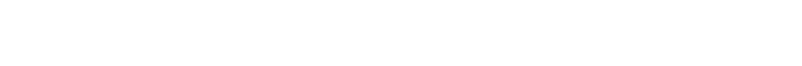

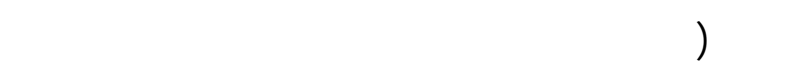

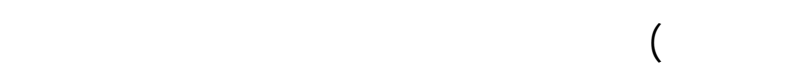

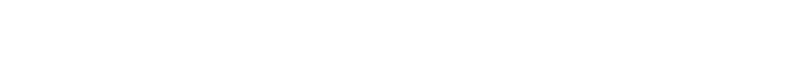

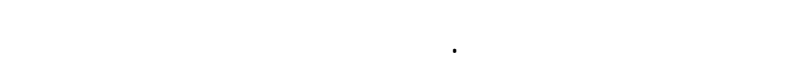

